\title{
Poetry of Resistance
}

\author{
Mahtab Alam*
}

*Correspondence: mdmahtabalam@gmail.com

Peer review: This article has been subject to a double blind peer review process

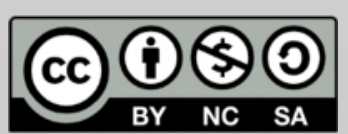

(C) Copyright: The Authors. This article is issued under the terms of the Creative Commons Attribution NonCommercial Share Alike License, which permits use and redistribution of the work provided that the original author and source are credited, the work is not used for commercial purposes and that any derivative works are made available under the same license terms.

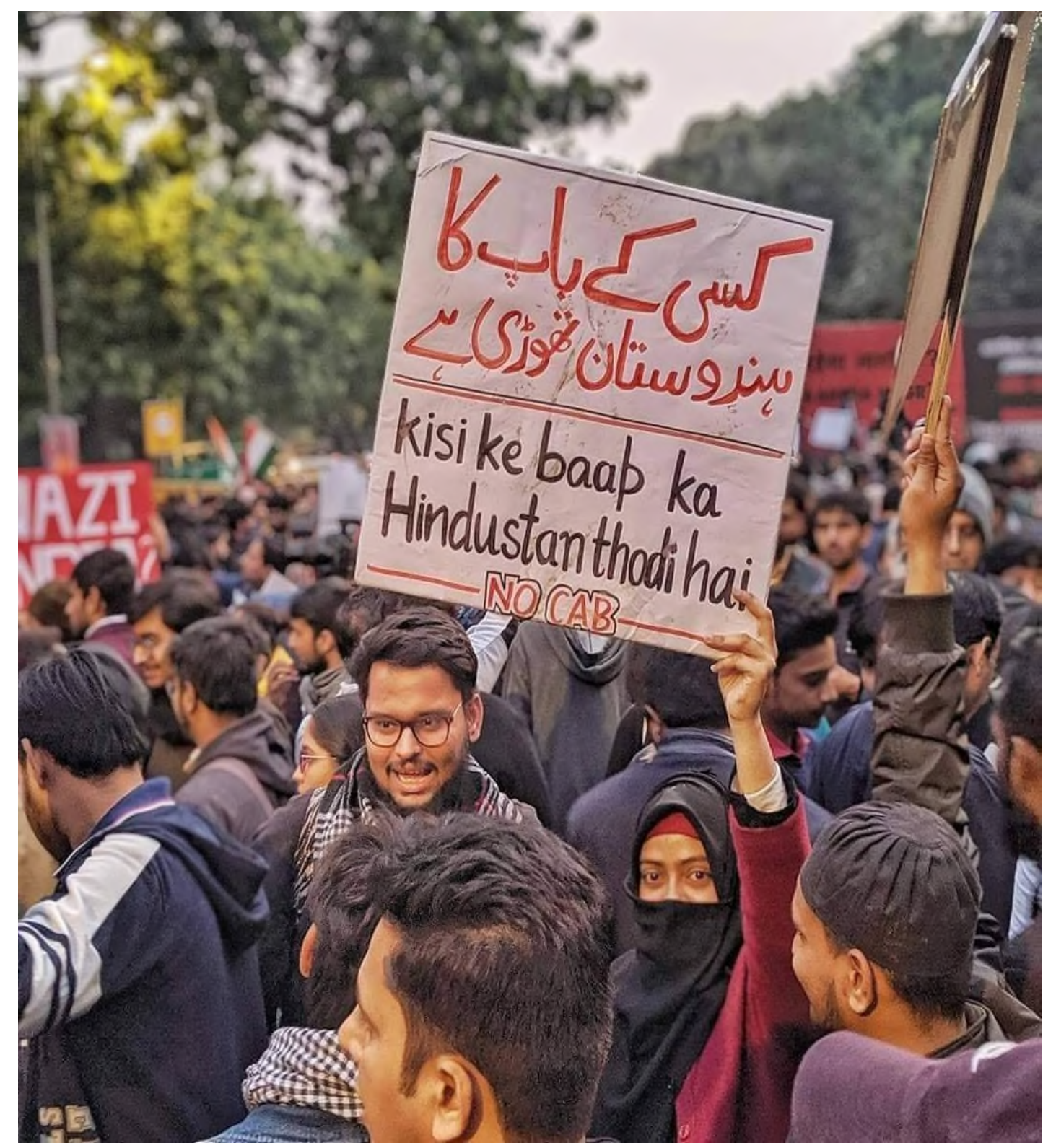

Protesters at Parliament Street, New Delhi, during an anti-CAA and anti-NRC protest. Photo by Anjum Alam 
Sabhi ka khoon shamil hai yahan ki mitti mein

kisi ke baap ka Hindustan thodi hai

Everyone's blood has seeped into the soil of this nation

This Hindustan (India) is no one's father's property

These lines by the noted Urdu poet and lyricist Rahat Indori, who died on 11 August 2020, reverberated as an anthem during the protests against the contentious Citizenship (Amendment) Act (CAA) and the National Register of Citizens (NRC). The CAA, passed by the Indian Parliament on December 12, 2019, accords the right to religious minorities from Pakistan, Bangladesh and Afghanistan to acquire Indian citizenship. At the same time, it directly excludes Muslims from that right. Combined with the expanding reach of the NRC, protests, sit-ins and solidarity meetings were mounted all across India and indeed across the globe against a law that was seen as fundamentally discriminatory. (UN News, 2019) The hundreds of thousands who came out to express their opposition to the Act, reiterated their faith in the ideals of equality and secularism that are an integral part of the Constitution of India.

Of course this was not the first time that such nationwide protests had taken place in postcolonial India, but the protests against the CAA and NRC stood out for the notable participation of Muslim women. Most of the protests, barring the ones in the north-east, were essentially led, organised and sustained by ordinary Muslim women, and challenged prevailing narratives about them as docile victims of Muslim patriarchal structures. The women at these protests sent out a clear message that asserted their rights as citizens of the nation, refusing to be silenced both at home and in the street. (Alam, 2020)

The protests were marked by a flowering of resistance poetry. The protestors sang and recited not only the works of poets like Indori and Faiz 
Ahmed Faiz, Habib Jalib, to name a few but found voice in a new movement that made poetry central to its resistance. Most of the poets were young men and women from different socio-economic backgrounds and regions of the country. Their poems were sung in the streets and went viral on the internet. These were the new radical citizens whose poetry spoke to a younger generation that wants to reject the old communal divides of religion and to sing of an inclusive nation.

The poetry appealed to people across the world, at a time when walls and borders are being redrawn with greater force. In February 2020, Pink Floyd guitarist and co-founder Roger Waters read out a part of the activist and poet Aamir Aziz's poem 'Sab Yaad Rakha Jayega' (Everything will be Remembered). Waters was speaking at an event in London, demanding the release of jailed Wikileaks founder Julian Assange. While reading the English version of the poem, Waters told the world that Aziz was fighting against the Indian Prime Minister Narendra Modi's 'fascist and racist Citizenship law.' (Indian Express, 2020)

However, much before the anti-CAA protests in the 'mainland', there were already struggles being carried out in Assam, a north-eastern state of India. In August 2019, the final version of the NRC was published. It effectively stripped about 1.9 million people of the state of their citizenship. People excluded from the list were allowed to appeal to special courts called Foreigners Tribunals, as well as the High Court and Supreme Court. However, if they were to lose their appeals in the higher courts, they could be thrown in detention centres, or worse, deported. As per news reports, more than 1,000 people are already languishing in six detention centres even as the government is building an exclusive new detention centre that can hold 3,000 detainees. (BBC New, 2019)

The protests in the north-east of India from 2016 onwards had given rise to a new form or school of poetry known as Miya poetry. The word Miya, 
though it literally means 'gentleman' in Urdu, is used as a slur in Assam for Bengali-origin Muslims who are seen as illegal immigrants. In July 2019, the state police registered a criminal case against ten people, most of them poets and activists who wrote in a dialect colloquially called the 'Miya' dialect. According to the complainant, the accused were trying 'to depict a picture of Assamese people as xenophobic in the eyes of the whole world, which [is] a serious threat to the Assamese people, as well as, towards the national security and harmonious social atmosphere. The real intention of this poem is to motivate and provoke their community against the system.' (Indian Express, 2019)

Following this complaint, several of them had to go underground for a while. Rehna Sultana, the lone female poet amongst the accused had to face sexual slurs because of her poetry and activism. Other poets face ongoing forms of harassment and intimidation as well. But they are not deterred-they are not only active but also determined to continue with their poetry and activism. During the lockdown in the face of the Covid-19 pandemic, they participated in several online and offline protests, apart from helping migrants and the needy in different parts of the country. I remember Rehna Sultana telling me, 'Getting scared or terrorised is not the solution. If we get scared, then the state and their allies will succeed in their design. But we will not let that happen.'

Here are some of the poems which were part of the protests.

Mahtab Alam is a Delhi based multilingual journalist, researcher and podcaster on politics, law, media, literature, environment and human rights. Mahtab is former executive editor of The Wire Urdu and currently writes for The Wire (in English, Urdu and Hindi) as well as BBC Urdu, the Independent Urdu, Down To Earth and Samkaleen Janmat. He is a guest podcaster with Sunolndia.in and the founder of Radio Urdu, an exclusive platform for Podcasts in Urdu. 


\section{References}

Alam, Mahtab (2020) Despite Opposition, Shaheen Bagh Stands Strong.

But What Next? [Online] Available from :

https://www.thequint.com/voices/opinion/despite-opposition-shaheenbagh-stands-strong-but-what-next [Accessed 25 November 2020 ]

BBC News (2019) Assam NRC: What next for 1.9 million 'stateless' Indians? [Online] Available from : https://www.bbc.com/news/worldasia-india-49520593 [Accessed 25 November 2020]

Indian Express (2019) : FIR against 10 for poem on Assam's citizenship row [Online] Available from : https://indianexpress.com/article/northeast-india/assam/fir-against-10-for-poem-on-assams-citizenship-row5825929/ [Accessed 25 November 2020]

Indian Express (2020) Pink Floyd guitarist Roger Waters recites Aamir Aziz's Sab Yaad Rakha Jayega [Online] Available from : https://indianexpress.com/article/entertainment/music/pink-floyd$\underline{\text { roger-waters-recites-aamir-aziz-sab-yaad-rakha-jayega-anti-caa-protest- }}$ watch-video-6289201/ [Accessed 25 November 2020 ]

UN News (2019) New citizenship law in India 'fundamentally discriminatory': UN human rights office [Online] Available from : https://news.un.org/en/story/2019/12/1053511 [Accessed 25 November 2020]

\section{To cite this article:}

Alam, M. (2020) 'Poetry of Resistance: From the anti-CAA protests in India', Feminist Dissent, (5), 275-279. Retrieved from: https://doi.org/10.31273/fd.n5.2020.769 